\title{
HPLC analytical method validation of Aralia elata extract as a functional ingredients
}

\author{
Eun-Mi Ahn ${ }^{1 *}$, Song-Am Choi ${ }^{2}$, Ji-Young Choi ${ }^{2}$ \\ ${ }^{1}$ Department of Foodceutical Science, Daegu Hanny University, Gyeongsan 38578, Korea \\ ${ }^{2}$ Dowellbio Inc., Gyeonggi Venture Incubation Center, Suwon 16229, Korea
}

두릅 추출물의 기능성 원료 표준화를 위한 HPLC 분석법 검증

\author{
안은미 $^{1 *} \cdot$ 최송암 ${ }^{2} \cdot$ 최지영 ${ }^{2}$ \\ ${ }^{1}$ 대구한의대학교 바이오산업융합학부, ${ }^{2}$ (주)두웰바이오
}

\begin{abstract}
Aralia elata Seemann (AE) has long been used as a folk medicine for the treatment of various diseases including diabetes mellitus, anti-arthritic, and anti-gastric ulcer agent in Korea, Japan, and China. This study was performed to establish a simple and reliable HPLC/UV analytical method for determination of most active anti-hypertensive compound, a 3-O- $\alpha-\mathrm{L}-$-rhamnopyranosyl $(1 \rightarrow 2)-\alpha-\mathrm{L}$-arabinopyranosyl hederagenin $28-O$ - $\beta$-D-xylopyranosyl $(1 \rightarrow 6)-\beta$ -D-glucopyranosylester (HE) for the standardization of the shoot extract of $\mathrm{AE}$ as a health functional food ingredient. The quantitative analytical method of HE was optimized by HPLC analysis using reverse-phase C18 column at $40^{\circ} \mathrm{C}$ with $\mathrm{H}_{2} \mathrm{O}$ and acetonitrile $(70: 30, \mathrm{v} / \mathrm{v})$ as an isocratic mobile phase at a flow rate of $1.0 \mathrm{~mL} / \mathrm{min}$ and detection wavelength of UV $205 \mathrm{~nm}$. This HPLC/UV analytical method showed good specificity and high linearity in the tested range of $0.03125-2.0 \mathrm{mg} / \mathrm{ml}$ with excellent coefficient of determination $\left(R^{2}\right)$ of 0.9999 . The limit of detection and limit of quantification were $12.0 \mu \mathrm{g} / \mathrm{mL}$ and $36.5 \mu \mathrm{g} / \mathrm{mL}$, respectively. Relative standard deviation (RSD) values of data from intra- and inter-day precision were less than $0.2 \%$ and $0.1 \%$, respectively. These results indicate that the established HPLC/UV analytical method is very simple, specific, precise, accurate, and reproducible and thus can be useful for the quantitative analysis of $\mathrm{HE}$ as a functional anti-hypertensive compound in $\mathrm{AE}$ extract.
\end{abstract}

Key words : Aralia elata, triterpenoid saponin, HPLC, analysis, validation

\section{서 론}

최근 고령화 사회로 진입이 가속화됨에 따라 건강, 장수 에 대한 인류의 욕망은 더 커져가고 있으며, 인삼 등 각종 약재를 이용한 다양한 식품, 생약추출물을 활용한 천연물 의약품 및 건강기능식품에 대한 관심도 함께 커져 가고 있다. 이에 따라 각종 제품의 품질관리를 위한 표준제조공 법 및 품질 규격화 방안 등이 시급히 요구되고 있다(1).

*Corresponding author. E-mail : ahnem@dhu.ac.kr Phone : 82-53-819-1462, Fax : 82-53-819-1272

Received 7 July 2017; Revised 15 August 2017; Accepted 21 August 2017.

Copyright (c) The Korean Society of Food Preservation. All rights reserved.
특히 생약재를 이용한 건강기능식품을 개발하고 생산하는 데 있어 원료 표준화 및 규격화는 중요한 부분을 차지하는 데, 원재료의 기능성과 안전성을 과학적으로 입증하기 위 해 지표성분의 함량을 통한 품질관리법이 유용하게 사용되 고 있다. 이러한 품질관리법은 제조공정에서 목표하는 성 분을 유지하기 위해 원재료에서 최종 제품까지 지표성분의 차이를 최소화 할 수 있도록 하는 가장 일반적인 방법이다. 지표성분은 원료의 표준화를 위해 선택되는 성분으로써 원재료의 사용 여부, 특이성, 대표성, 안전성, 분석기술의 용이성, 안전성 등을 고려하여야 한다. 이와 같이 지표성분 을 확인하는 방법은 공인된 방법이나 정밀하다고 판단되는 분석방법을 사용하며 신뢰성을 가지는 과학적인 검증으로 시험법 validation이 필요하게 된다(2).

두릅나무(Aralia elata Seem.)은 두릅나무과에 속하는 낙 
엽 활엽 관목으로 전국 산지에 자생하며 예로부터 민간에서 식용, 약용으로 이용해 왔다. 그 중에도 비교적 질기지 않은 새순은 봄에 채취하여 식용으로 사용되고 있다. 두릅 나무의 어린순과 줄기는 특유의 향과 약간 쓴 맛이 있어 기호식품으로 각광받고 있는 가운데 식용 가능한 야생 식물 들의 새로운 식품학적 가치가 인정되면서 농가소득 증대를 위한 대체작물로 생산량이 점차 증가하고 있는 추세이다. 두릅의 주요 성분은 oleanolic acid, sitosterol, choline, hederagenin, congmuyanosides A, C, D, echinocystic acid, palmitic acid, linoleic acid, methyl eicosanoate, 3,4dihydroxybenzoic acid 등 다양한 성분 연구뿐만 아니라 뿌 리, 과실, 수피 등의 당뇨병, 신장병, 급성간염, 류마티스성 관절염, 위암, 위장장애에 관한 다양한 연구들도 보고된 바 있다(3-11).

본 연구는 두릅나무 순의 다양한 생리 활성 기능 중 항고 혈압 활성이 있는 것으로 보고된 결과 $(12,13)$ 를 토대로 이를 이용한 혈압조절용 개별인정형 건강기능식품의 기능성 원 료로의 개발을 목적으로 기능성 성분인 3-O-a-Lrhamnopyranosyl $(1 \rightarrow 2)$-a-L-arabinopyranosyl hederagenin28$O$ - $\beta$-D-xylopyranosyl $(1 \rightarrow 6)-\beta$-D-glucopyranosyl ester(HE) 를 지표성분으로 설정하여(Fig. 1), 두릅 추출물의 표준화 및 규격화를 위하여 $\mathrm{HE}$ 의 분석법을 확립하며 그에 따른 유효성 검증을 실시하고자 하였다.

일반적으로 지표성분의 분석에는 HPLC를 주로 사용하 지만(14), triterpenoid saponin계 화합물은 UV 흡광이 약하 기 때문에 HPLC/UV 분석방법의 적용이 어려워 UV 검출기 를 대체하여 evaporative light scattering detector(ELSD) 또 는 charged aerosol detector(CAD)를 사용하는 것으로 알려 져 있으며, 최근에는 UV 흡광이 없거나 약한 화합물의 검출 을 위해서 mass spectrometric detection 방법도 많이 사용하 고 있다 $(15,16)$. 또한 $\mathrm{UV}$ 흡광이 나타나는 저파장으로 검출 하는 경우에는 다른 화합물들에 의한 간섭으로 인하여 원하 는 성분을 특이적으로 검출하는데 한계가 있다. 그러나 본 연구에서는 추가적인 검출기를 사용하지 않고 HPLC/UV 분석방법을 적용하여 두릅나무 순 추출물 중에 함유된 기능 성분인 triterpenoid saponin계열의 $\mathrm{HE}$ 에 대한 효율적인 정 량분석법을 확립하고 그 유효성을 검증하였다.

\section{재료 및 방법}

\section{두릅 추출물 제조}

본 실험에 사용한 두릅은 2016년 6월 제주도에서 자생하 는 두릅나무의 순을 채취하여 제주대학교 생물학과 김문홍 교수가 동정하여 확인된 것을 사용하였다. 채취한 두릅을 잘 건조하고 분쇄한 후 시료 중량의 10 배량의 $70 \%$ 발효 에탄올(Samchun, Pyeongtaek, Korea) 용매를 첨가한 후 5 $0^{\circ} \mathrm{C}$ 에서 약 12 시간씩 2 회 가열 추출하였다. 추출 후 여과 및 농축하여 동결 건조하여 사용하였다.

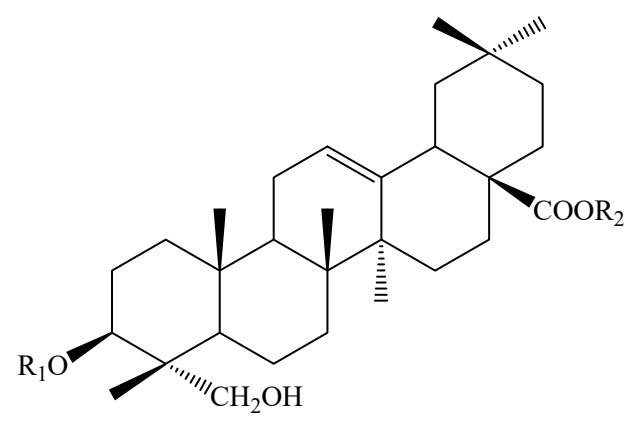

$$
\begin{array}{cc}
\mathbf{R}_{\mathbf{1}} & \mathbf{R}_{\mathbf{2}} \\
\text { 1: }-\mathrm{Ara}^{2}-\mathrm{Rha} & -\mathrm{Glc}^{6}-\mathrm{Xyl}
\end{array}
$$

Fig. 1. Chemical structure of 3-O- $a-L-r h a m n o p y r a n o s y l(1 \rightarrow 2)-a$ -L-arabinopyranosyl hederagenin 28-O- $\beta$-D-xylopyranosyl $(1 \rightarrow 6)-\beta$ -D-glucopyranosyl ester (HE).

\section{시약 및 분석기기}

분석에 사용한 $\mathrm{HE}$ 표준품은 두릅나무의 순으로부터 분 리 정제하고 Varian Unity Inova 400FT NMR(California, USA)을 이용하여 구조를 확인한 순도 $99.0 \%(\mathrm{HPLC})$ 를 사 용하였다. HPLC 분석 및 시료 조제에 사용한 용매 및 이동 상은 모두 HPLC급으로 J.T. Baker(Phillipsburg, NJ, USA)사 의 제품을 사용하였다. 또한 PDA 측정을 위해 Agilent 1260 Infinity II system(Santa Clara, USA)의 검출기는 Agilent $1260 \mathrm{DAD} W R(\mathrm{G} 7115 \mathrm{~A})$ 을 사용하였고 모든 분석 조건은 동일하게 사용하였다.

Table 1. Analytical conditions of HPLC for HE in Aralia elata extract

\begin{tabular}{cc}
\hline Parameters & Condition \\
\hline HPLC model & Shimadzu LC-10 \\
Column & Shiseido Capcellpak ${ }^{\circledR} \mathrm{C}_{18}(5 \mu \mathrm{m}, 4.6 \times 250 \mathrm{~mm})$ \\
Detector & UV $205 \mathrm{~nm}$ \\
Flow rate & $1.0 \mathrm{~mL} / \mathrm{min}$ (isocratic) \\
Column temperature & $40^{\circ} \mathrm{C}$ \\
Injection volume & $10 \mu \mathrm{L}$ \\
Mobile phase & Acetonitrile: $\mathrm{H}_{2} \mathrm{O}(0.1 \%$ Formic acid $)=30: 70$ \\
\hline
\end{tabular}

\section{표준용액의 조제}

표준품(HE) $20.0 \mathrm{mg}$ 을 사용 전 검교정이 완료된 미세저 울로 정확하게 칭량하여 $10 \mathrm{~mL}$ volumetric flask에 넣고 HPLC 등급의 methanol을 넣어 녹여 정확하게 $10 \mathrm{~mL}$ 표선 을 맞춰 $2,000 \mu \mathrm{g} / \mathrm{mL}$ 농도의 stock solution을 조제하였다. 조제된 stock solution은 $4^{\circ} \mathrm{C}$ 에 보관하여 사용 전에 희석하여 사용하였다. 


\section{시험용액의 조제}

추출 후 여과 및 농축하여 동결 건조한 뒤 얻어진 두릅 추출물 $1.0 \mathrm{~g}$ 을 정확히 취하여 $100 \mathrm{~mL}$ volumetric flask에 넣고 HPLC 등급의 methanol을 가하여 표선을 맞추어 시험 용액으로 하였다. 시험용액은 사용 전 $0.45 \mu \mathrm{m}$ syringe filter 로 여과하여 검액으로 사용하였다.

\section{HPLC 분석법의 유효성 검증}

HPLC 분석법 검증을 위하여 식품의약품안전처의 “의약 품 등 시험방법 밸리데이션 가이드라인 $(17,18)$ 을 근거로 특이성(specificity), 직선성 및 범위(linearity and range), 정 확성(accuracy), 반복성(repeatability), 실험실내 정밀성 (intermediate precision) 및 완건성(robustness)을 조사하였 고, 직선성 검증을 통해 얻은 검량선의 기울기와 표준편차 를 통해 검출한계(LOD) 및 정량한계(LOQ)를 조사하였으 며 이를 이용하여 두릅추출물 중 기능성 지표성분인 $\mathrm{HE}$ 의 함량을 분석하였다.

\section{특이성 (specificity)}

특이성이란 불순물, 분해 생성물, 첨가물 등이 혼재되어 있는 상태에서 분석대상물질을 선택적으로 정확하게 측정 할 수 있는 능력을 의미하며, 시료에서 분석대상물질을 선 택적으로 측정할 수 있는 정도를 나타내는 특이성의 검증을 위하여 표준용액과 시험용액을 HPLC로 분석한 뒤 크로마 토그램을 비교하여 표준물질의 peak가 분리되는지를 확인 하였고 peak간 간섭 정도를 측정하였다. 분석에 필요한 blank $(\mathrm{MeOH})$, 표준용액 $(\mathrm{HE}, 1.0 \mathrm{mg} / \mathrm{mL})$, 시험용액(두릅추 출물, $1.0 \mathrm{~g} / 100 \mathrm{~mL} \mathrm{MeOH})$, 검액 $(\mathrm{HE} 2.0 \mathrm{mg} / \mathrm{mL}$ 농도의 표준원액+시험용액)을 조제한 뒤 $0.45 \mu \mathrm{m}$ 실린지 필터로 여과하여 분석에 사용하였으며, 조제된 blank, 표준용액, 시험용액 및 검액을 각각 1 회 분석하고 이 때 $\mathrm{HE}$ 주피크에 간섭이 없음을 확인하였고, 표준액과 시험용액 및 검액의 주피크 유지시간이 동일함을 확인하였다. $\mathrm{HE}$ 표준용액과 두릅 추출물을 HPLC로 분석한 뒤 크로마토그램상의 retention time과 비교하여 $\mathrm{HE}$ 피크가 분리되는지 확인하였 다. 또한 photo diode array(PDA) spectrum을 측정하여 동일 한 spectrum을 나타내는지도 확인하였다.

\section{직선성(linearity) 및 범위(range)}

시험방법이 일정한 범위 내에 있는 검체 중 분석대상물 질의 양 또는 농도에 대하여 직선적인 측정값을 얻어낼 수 있는 능력을 의미하는 직선성을 검증하기 위해 7개 농도 의 검체를 3 반복하여 분석 후 얻은 값의 피크 면적비와 농도비의 관계를 알 수 있는 회귀분석을 통하여 표준 검량 선을 얻었다. $\mathrm{HE}$ 표준품을 methanol에 용해시켜 분석에 필요한 각각 다른 농도 범위로 $0.03125 \mathrm{mg} / \mathrm{mL}, 0.0625$ $\mathrm{mg} / \mathrm{mL}, 0.125 \mathrm{mg} / \mathrm{mL}, 0.250 \mathrm{mg} / \mathrm{mL}, 0.5 \mathrm{mg} / \mathrm{mL}, 1.0 \mathrm{mg} / \mathrm{mL}$,
$2.0 \mathrm{mg} / \mathrm{mL}$ 를 만든 후 HPLC에 주입하고 각 농도별 표준액 을 각 3 회씩 주입하여 $\mathrm{HE}$ 주입농도와 피크면적간의 결정계 수, 기울기, $\mathrm{y}$ 절편을 구하였다.

\section{정확성 (accuracy)}

측정값이 이미 알고 있는 참값이나 표준값에 근접한 정 도로서 실측치가 참값에 얼마나 가까운 가를 의미하는 정확 성을 검증하기 위해 $\mathrm{HE}$ 표준용액 $(2.0 \mathrm{mg} / \mathrm{mL})$ 에 methanol을 가하여 최종농도가 $0.5 \mathrm{mg} / \mathrm{mL}, 1.0 \mathrm{mg} / \mathrm{mL}, 1.5 \mathrm{mg} / \mathrm{mL}$ 가 되도록 검액을 조제하고 각각 3 회씩 분석하였다. 직선성 시험에서 얻은 검량선을 이용하여 각 검액의 실측 농도 값을 구하였고, 실제 첨가된 이론 농도값에 대한 회수율(\%) 을 구하여 기준에 적합한지 확인하였다.

\section{정밀성 (precision)}

동일 실험자가 동일한 장치와 기구, 동일한 시료, 동일한 조작 조건하에서 균일한 검체로부터 얻은 복수의 검체를 짧은 시간차로 반복분석 실험하여 얻은 측정값들 사이의 근접성(분산정도)을 의미하는 반복성 실험과 실험실내에 서 실험일, 시험자, 기구, 기기 등을 바꿔 측정값 간의 정밀 성을 검증하기 위해 표준용액과 같은 농도로 조제한 시료를 분석하여 검량선을 작성한 다음, 시험용액에 $\mathrm{HE}$ 표준원액 을 spiking하여 최종 농도 $1.0 \mathrm{mg} / \mathrm{mL}$ 로 조제한 검액을 분석 하며 전 조작을 6회 반복 시험하여 반복성(repeatability)과 실험실내 정밀성(intermediate precision)을 확인하였다. 시 험을 통해 6회 측정한 농도 값들 간의 평균, 표준편차, 상대 표준편차(relative standard deviation, RSD \%)를 구하였다.

\section{완건성 (robustness)}

시험방법 중 일부 조건이 소규모라도 의도적으로 변경되 었을 때 측정값이 얼마나 영향을 받는지에 대한 척도로써 표준화된 시험방법에서 시험조건을 변동할 수 있도록 설정 해 놓은 범위보다 더 넓은 범위를 의도적으로 변동시켜서 검토하였다. 본 실험에서는 시험용액의 안정성 인자의 검 증을 위하여 특이성 시험에서 조제한 검액을 상온에서 autosampler에 보관하면서 10시간 후, 20시간 후, 24시간 후에 각각 3 회씩 재분석하여 $\mathrm{HE}$ 피크면적의 상대표준편차 (RSD)를 구하여 일상적으로 수행하는 시험방법의 타당성 이 유지되고 있음을 검증하였다.

\section{검출한계(LOD) 및 정량한계(LOQ)}

직선성 검증을 통해 얻은 검량선의 기울기와 표준편차를 통해 검출한계 및 정량한계를 구하였으며, 지표성분 $\mathrm{HE}$ 의 검출한계(limit of detection, LOD)는 시료에 포함되는 지표 성분의 검출이 가능한 최소량 또는 최저 농도, 정량한계 (limit of quantification, LOQ)는 시료에 포함되어 있는 지표 성분의 정량이 가능한 최소량 또는 최저 농도로서 $\mathrm{LOD}$ 와 
$\mathrm{LOQ}$ 는 반응의 표준편차와 검량선의 기울기에 근거하여 산출하였다.

$\mathrm{LOD}=3.3 \times$ standard deviation of the response/slope of the calibration curve

$\mathrm{LOQ}=10 \times$ standard deviation of the response/slope of the calibration curve

\section{두릅추출물 중 $\mathrm{HE}$ 함량 분석}

제주산 건조 두릅추출물에 함유된 기능성 지표성분인 $\mathrm{HE}$ 의 함량을 분석하기 위해 $1.0 \mathrm{~g} / 100 \mathrm{~mL}$ 농도의 시료를 3회 반복 분석하였으며 표준용액의 크로마토그램의 피크 면적을 통하여 작성된 검량선에 의해 두릅추출물 시료 중 함유된 $\mathrm{HE}$ 의 함량을 산출하였다.
석을 실시하기 위해 column, 이동상의 종류 및 UV검출 파 장을 최적화하여 분석을 진행하였으며, 그 결과는 Table 1 과 같다.

\section{특이성 확인}

표준용액과 조제된 두릅추출물 시험용액의 크로마토그 램을 비교하여 함유된 표준물질의 피크가 분리되는지를 확인한 결과, 다른 물질과 간섭 없이 단일한 피크로 분리되 었으며 표준용액의 피크유지시간과 시험용액의 피크 유지 시간 또한 일치하였다(Fig. 2). 또한 표준용액과 시험용액의 PDA spectrum을 측정한 결과에서도 190-240 nm에서 동일 한 spectrum을 나타내어 본 시험법의 특이성을 확인하였다.

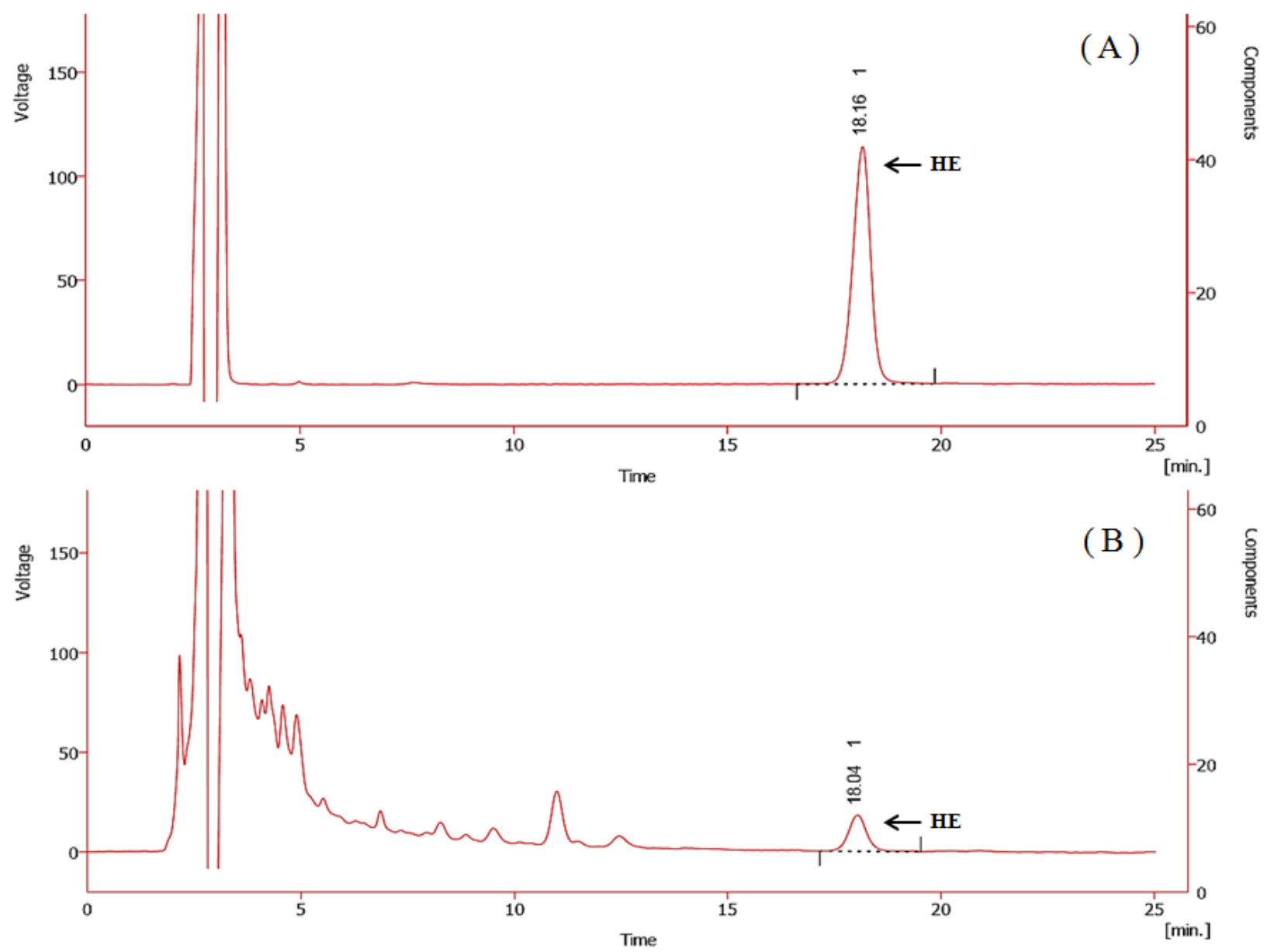

Fig. 2. The HPLC chromatograms of HE $(1.0 \mathrm{mg} / \mathrm{mL})$ (A) standard and (B) Aralia elata extract $(1.0 \mathrm{~g} / 100 \mathrm{~mL})$.

\section{결과 및 고찰}

\section{분석조건의 확립}

두릅나무 순 추출물의 지표성분인 HE(Fig. 1)에 대한 분
직선성 및 범위

각 농도별로 단계적으로 조제한 표준용액을 HPLC로 분 석하여 피크 면적비에 대한 농도비의 관계를 표시하는 표준 검량선을 작성하였다. 측정한 $0.03125-2.0 \mathrm{mg} / \mathrm{mL}$ 의 농도범 위에서 3 회 분석하여 작성한 검량선의 결정계수(R2)는 


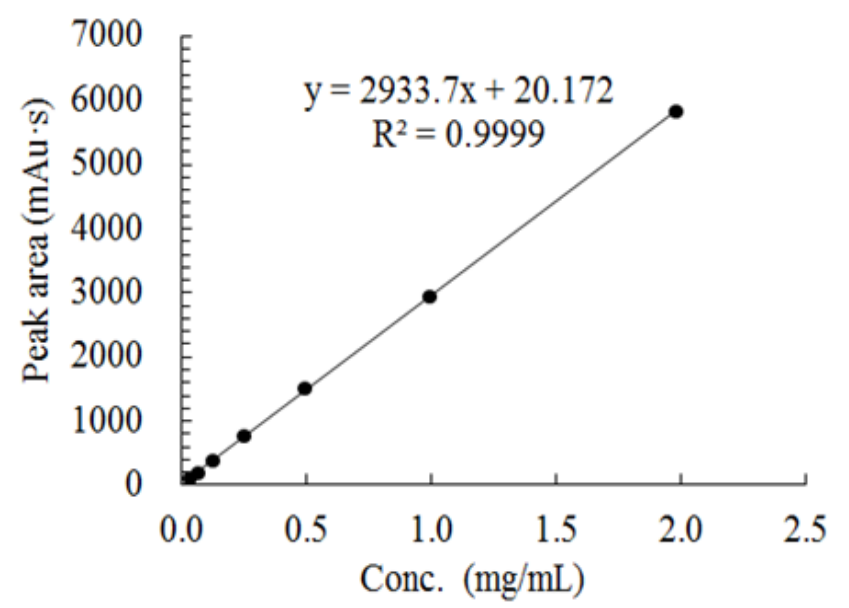

Fig. 3. Calibration curve of HE.

Table 2. Recoveries and relative standard deviations of $\mathrm{HE}$ in HPLC analysis for validation

\begin{tabular}{cccc}
\hline $\begin{array}{c}\text { Concentration } \\
(\mathrm{mg} / \mathrm{mL})\end{array}$ & Recovery $(\%)$ & Mean $\pm \mathrm{SD}^{1)}$ & RSD (\%) \\
\hline \multirow{4}{*}{1.50} & 100.5 & & \\
& 103.7 & $101.8 \pm 1.674$ & $0.019 \pm 0.010$ \\
& 101.3 & & \\
\hline \multirow{4}{*}{00} & 102.4 & & \\
& 104.3 & $104.7 \pm 2.536$ & $0.018 \pm 0.012$ \\
0.50 & 107.4 & & \\
& 98.0 & & \\
& 99.7 & $98.8 \pm 0.865$ & \\
\hline${ }^{1)}$ Each values was the mean \pm SD. \\
${ }^{22}$ Relative standard deviation.
\end{tabular}

0.9999이상의 높은 직선성을 보였다(Fig. 3).

\section{정확성}

지표성분을 농도별로 시험용액을 조제하여 각 3회씩 분 석한 결과, Table 2에 나타난 바와 같이 표준물질의 회수율 은 $0.5 \mathrm{mg} / \mathrm{mL}$ 의 농도에서는 $98.8 \pm 0.865,1.0 \mathrm{mg} / \mathrm{mL}$ 의 농도 에서는 $104.7 \pm 2.536$ 그리고 $1.5 \mathrm{mg} / \mathrm{mL}$ 에서는 $101.8 \pm 1.674$ 의 범위의 높은 회수율을 보였으며, 분석오차 $0.013 \%$ 를 나타내었다.

\section{정밀성}

반복성(repeatability)과 실험실내 정밀성(intermediate precision)으로 시험하였으며 정밀도(RSD)를 측정한 결과 는 Table 3 과 같다. 반복성 시험에서는 $1.0 \mathrm{mg} / \mathrm{mL}$ 의 농도로 조제한 시험용액을 6 회 반복하여 분석한 측정값이 평균 $101.5 \pm 0.4 \%, \mathrm{RSD} 0.4 \%$ 를 나타내었고, 실험실내 정밀성의 1 차 시험에서 $1.0 \mathrm{mg} / \mathrm{mL}$ 의 농도로 조제한 시험용액의 측정 값이 평균 $107.2 \pm 0.2 \%, 2$ 차 시험에서의 측정값은 $107.2 \pm$ $0.1 \%$ 를 나타남으로써 1 차 시험과 2 차 시험간의 $\mathrm{RSD}$ 는
$0.2 \%$ 로 적합함을 확인하였다.

완건성

개발된 분석법이 정량분석에 가능한 재현성을 가지고 있다는 것을 증명하기 위해 특이성 시험에서 조제한 검액을 상온에서 autosampler에 보관하면서 0 시간, 10 시간, 20 시간, 24시간 동안 시험용액의 안정성을 평가한 결과는 Table 4 와 같다. 0 시간, 10 시간, 20 시간, 24 시간 후 각 시료를 3 회 반복하여 측정한 $\mathrm{RSD}$ 는 각각 $0.3,0.1,0.2,0.2 \%$ 로 나타났으 며 판정기준 $2.0 \%$ 이하인 것을 확인하였고 이러한 결과는 개발된 분석법이 일상의 정량분석에 적용 가능한 재현성을 가지고 있다는 것으로 확인되었다.

Table 3. Precision data of analytical method for HE in Aralia elata extract

\begin{tabular}{ccccc}
\hline Precision & $\begin{array}{c}\text { Concentration } \\
(\mathrm{mg} / \mathrm{mL})\end{array}$ & Recovery $(\%)$ & Mean \pm SD $^{1)}$ & RSD $(\%)^{2)}$ \\
\hline & & 101.7 & & \\
Repeatability & 1.0 & 101.3 & & \\
& & 101.1 & $101.5 \pm 0.4$ & 0.4 \\
& & 102.1 & & \\
& & 101.1 & & \\
& & 107.1 & & \\
Intermediate & 1.0 & 107.5 & & \\
precision & & 107.3 & $107.2 \pm 0.2$ & \\
& & 107.4 & & \\
& & 107.0 & & \\
& & 107.1 & & \\
& & 107.3 & & \\
& 1.0 & 107.2 & & \\
& & 107.0 & $107.2 \pm 0.1$ & \\
& & 107.2 & & \\
& & 107.3 & & \\
& & 107.0 & & \\
\hline
\end{tabular}

${ }^{1)}$ Each values was the mean $\pm \mathrm{SD}$.

${ }^{2)}$ Relative standard deviation.

\section{정량한계 및 검출한계}

직선성 검증을 통해 얻은 검량선의 기울기와 표준편차 $\mathrm{y}$ 절편)를 통해 검출한계를 구한 결과, 검출한계는 $12.0 \mu$ $\mathrm{g} / \mathrm{mL}$, 정량한계는 $36.5 \mu \mathrm{g} / \mathrm{mL}$ 수준으로 나타났다. 이는 두 릅추출물 시료에 적용할 경우, 두릅추출물은 기능성분 $\mathrm{HE}$ 의 함량이 약 $4 \%$ 수준을 함유하고 있으므로 두릅추출물에 서의 검출한계 및 정량한계는 각각 $30 \mathrm{mg} / 100 \mathrm{~mL}$ 및 91 $\mathrm{mg} / \mathrm{mL}$ 로 확인되었다.

\section{두릅추출물 중 $\mathrm{HE}$ 함량 분석}

제주산 건조 두릅을 $70 \%$ 발효에탄올로 추출, 농축하여 제조한 시료 중에 함유된 $\mathrm{HE}$ 의 함량을 분석하였다. 두릅추 출물 시료 $1.0 \mathrm{~g}$ 을 정밀하게 취하여 메탄올에 녹여 100 
Table 4. Robustness data of HE

\begin{tabular}{|c|c|c|c|c|}
\hline \multirow{13}{*}{ Robustness } & Time (h) & Peak area & Mean $\pm \mathrm{SD}^{1)}$ & $\operatorname{RSD}(\%)^{2)}$ \\
\hline & \multirow{3}{*}{ Initial } & 3403 & \multirow{3}{*}{$3,401 \pm 8.6$} & \multirow{3}{*}{0.3} \\
\hline & & 3392 & & \\
\hline & & 3409 & & \\
\hline & \multirow{3}{*}{10} & 3392 & \multirow{3}{*}{$3,396 \pm 4.7$} & \multirow{3}{*}{0.1} \\
\hline & & 3394 & & \\
\hline & & 3401 & & \\
\hline & \multirow{3}{*}{20} & 3390 & \multirow{3}{*}{$3,395 \pm 8.4$} & \multirow{3}{*}{0.2} \\
\hline & & 3391 & & \\
\hline & & 3405 & & \\
\hline & \multirow{3}{*}{24} & 3407 & \multirow{3}{*}{$3,400 \pm 6.1$} & \multirow{3}{*}{0.2} \\
\hline & & 3399 & & \\
\hline & & 3395 & & \\
\hline
\end{tabular}

${ }^{1}$ Each values was the mean $\pm S D$.

${ }^{22}$ Relative standard deviation.

$\mathrm{mL}$ 조제한 용액을 3회 반복하여 분석하였을 때, 두릅추출 물 중에는 $4.88 \pm 0.01 \%(\mathrm{RSD} 0.41 \%)$ 의 $\mathrm{HE}$ 가 함유되어 있음 을 확인하였다.

이상의 분석결과, 본 연구의 기기분석법과 유효성검증을 통해 두릅순의 지표물질인 triterpenoid saponin 계열의 성분 을 정량분석하는데 있어 추가적인 기기의 설비 없이도 일반 적인 검출기인 $\mathrm{HPLC} / \mathrm{UV}$ 법을 적용하여 간편하게 $\mathrm{HE}$ 를 정 량할 수 있는 분석방법을 개발하여 그 타당성을 검증하였 다. 따라서 이러한 결과를 토대로 건강기능식품 기능성 원 료로서 두릅나무 순 추출물의 지표성분인 $\mathrm{HE}$ 의 분석이 가능함을 확인하였다.

\section{요 약}

개별인정형 건강기능식품 기능성 원료로 개발한 두릅추 출물의 표준화를 위해 항고혈압활성 효과를 가지고 있는 기능성분 $\mathrm{HE}$ 를 지표성분으로 설정하고, HPLC/UV 방법을 이용하여 기능성분 분석법을 확립하며 그에 따른 유효성 검증을 실시하고자 하였다. 유효성 검증 결과, 본 시험법에 서 표준용액의 피크유지시간과 두릅추출물의 피크유지시 간이 일치하였다. 검량선의 결정 계수(R2)는 0.9999 이상의 높은 직선성을 보여 분석에 적합함을 알 수 있었으며, 검출 한계는 $12.0 \mathrm{\mu g} / \mathrm{mL}$, 정량한계는 $36.5 \mathrm{\mu g} / \mathrm{mL}$ 로 두릅 추출물 중의 $\mathrm{HE}$ 함량분석을 위한 충분한 한계 수준으로 확인되었 다. 정확성에서 $98.8 \pm 0.865-104.7 \pm 2.536 \%$ 로 높은 수준의 $\mathrm{HE}$ 회수율을 보였으며, 평균 분석오차는 $0.013 \%$ 로서 기준 인 $10 \%$ 이내를 만족하였다. 또한 반복성에서는 평균 $101.5 \pm 0.4 \%$ 로 RSD $0.4 \%$ 를 나타내었고, 실험실내 정밀성 에서 $\mathrm{RSD} 0.2 \%$, 완건성에서 $\mathrm{RSD} 0.2 \%$ 를 나타내어 모두 적합함을 확인하였다. 한편, 제주산 두릅추출물 중에는 기 능성 지표성분인 $\mathrm{HE}$ 가 $4.88 \%$ 함유되어 있는 것으로 확인
되었다. 이상의 실험 결과, 두릅추출물의 항고혈압활성 기 능성분인 $\mathrm{HE}$ 의 $\mathrm{HPLC} / \mathrm{UV}$ 분석방법은 특이성, 직선성, 정 확성, 정밀성, 반복성, 완건성 등의 모든 항목에서 validation 기준에 적합한 시험 방법으로 확인되었다.

\section{Acknowledgment}

This work was supported by the Technological Innovation R\&D Program (S2335011) funded by the Small and Medium Business Administration (SMBA, Korea).

\section{References}

1. Yoo DS, Choi YH, Cha MR, Choi CW, Kim MR, Yon GH, Hong KS, Lee BH, Kim EJ, Cho SW, Kim YS, Ryu SY, Kang JS (2010) Variation of saponin contents in the decoctions of Platycodi $\operatorname{Radix}(\Pi)$. Kor $\mathrm{J}$ Pharmacogn, 41, 147-152

2. KFDA (2007) Guideline for standard of health functional food. Korea Food and Drug Administration, Korea, $p$ 6-13

3. Lee TB (1985) Illustrated flora of Korea. Hangmunsa, Seoul, Korea, p 575

4. Lee GH, Jung JW, Ahn EM (2009) Antioxidant activity of isolated compounds from the shoot of Aralia elata Seem. Kor J Herbology, 24, 137-142

5. Ma H, Song S, Liu F, Zhang Y, Peng Y (2014) Simultaneous determination of five triterpenoid $\mathrm{s}$ aponins in different parts of Aralia elata by high performance liquid chromatography-tandem mass spectrometry. Se $\mathrm{Pu}$, 32, $762-766$

6. Ma ZQ, Zhang Y, Cai CK, Li Q, Ni J (2013) Two new triterpenoid saponins from the leaves of Aralia elata. $\mathrm{J}$ Asian Nat Prod Res, 15, 849-854

7. Wang Z, Wu Q, Meng Y, Sun Y, Wang Q, Yang C, Wang Q, Yang B, Kuang H (2015) Determination and pharmacokinetic study of two triterpenoid saponins in rat plasma after oral administration of the extract of Aralia elata leaves by UHPLC-ESI-MS/MS. J Chromatogr B Analyt Technol Biomed Life Sci, 15, 164-171

8. Guo M, Zhang L, Liu Z (2009) Analysis of saponins from leaves of Aralia elata by liquid chromatography and multi-stage tandem mass spectrometry. Anal Sci, 25, 753-758

9. Song SJ, Nakamura N, Ma CM, Hattori M, Xu SX (2001) 
Five saponins from the root bark of Aralia elata. Phytochemistry, 56, 491-497

10. Song SJ, Nakamura N, Ma CM, Hattori M, Xu SX (2000) Four new saponins from the root bark of Aralia elata. Chem Pharm Bull, 48, 838-842

11. Kim JS, Shim SH, Chae SW, Han SJ, Kang SS, Son KH, Chang HW, Kim HP, Bae KH (2005) Saponins and other constituents from the leaves of Aralia elata. Chem Pharm Bull, 53, 696-700

12. Jin JY (2008) Protective effects of triterpenoid saponins from Aralia elata on endothelial dysfunction in hypertension. $\mathrm{Ph} \mathrm{D}$ Thesis, Jeju National University, Korea, p 78-84

13. Joo CW (2002) Vasorelaxant effects of methanolic extract of Aralia elata SEEM. on the isolated rat and rabbit aorta. MS Thesis, Jeju National University, Korea, p 8-16

14. Cho SH, Lee JM, Lee YK, Chung MJ, Kwon KH, Lee
SH (2016) Determination of pectolinarin in Cirsium spp. using HPLC/UV analysis. J Appl Biol Chem, 59, 107-112

15. Yeom H, Suh JH, Youm JR, Han SB (2010) Simultaneous determination of triterpenoid saponins from Pulsatilla koreana using high performance liquid chromatography coupled with a charged aerosol detector (HPLC-CAD). Bull Korean Chem Soc, 31, 1159-1164

16. Park SB, Chun JH, Ban YW, Han JY, Choi YE (2016) Alteration of Panax ginseng saponin composition by over expression and RNA interference of the protopanaxadiol 6-hydroxylase gene. J Ginseng Res, 40, 47-54

17. Ministry of Food and Drug Safety. http://www.mfds. go.kr/index.do? $\mathrm{mid}=1162 \& \mathrm{seq}=5549 \& \mathrm{cmd}=\mathrm{v}$ (accessed September 2012)

18. Ministry of Food and Drug Safety. http://www.mfds.go. $\mathrm{kr} / \mathrm{index} \cdot \mathrm{do} ? \mathrm{mid}=1162 \& \mathrm{seq}=10382 \& \mathrm{cmd}=\mathrm{v}($ accessed December 2015) 